\title{
Host-exclusivity and host-recurrence by wood decay fungi (Basidiomycota - Agaricomycetes) in Brazilian mangroves
}

\author{
Georgea S. Nogueira-Melo ${ }^{1 *}$, Paulo J. P. Santos ${ }^{2}$ and Tatiana B. Gibertoni ${ }^{1}$
}

Received: April 7, 2017

Accepted: May 9, 2017

\begin{abstract}
This study aimed to investigate for the first time the ecological interactions between species of Agaricomycetes and their host plants in Brazilian mangroves. Thirty-two field trips were undertaken to four mangroves in the state of Pernambuco, Brazil, from April 2009 to March 2010. One 250 x 40 m stand was delimited in each mangrove and six categories of substrates were artificially established: living Avicennia schaueriana (LA), dead A. schaueriana (DA), living Rhizophora mangle (LR), dead R. mangle (DR), living Laguncularia racemosa (LL) and dead L. racemosa (DL). Thirty-three species of Agaricomycetes were collected, 13 of which had more than five reports and so were used in statistical analyses. Twelve species showed significant values for fungal-plant interaction: one of them was hostexclusive in DR, while five were host-recurrent on A. schauerianna; six occurred more in dead substrates, regardless the host species. Overall, the results were as expected for environments with low plant species richness, and where specificity, exclusivity and/or recurrence are more easily seen. However, to properly evaluate these relationships, mangrove ecosystems cannot be considered homogeneous since they can possess different plant communities, and thus different types of fungal-plant interactions.
\end{abstract}

Keywords: Fungi, estuaries, host-fungi interaction, host-relationships, plant-fungi interaction

\section{Introduction}

Wood decay fungi are mostly macroscopic Basidiomycota usually known as mushrooms, bracket fungi and earthstars. They occur in different habitats, being found with higher frequency and abundance in forests. They are able to degrade lignin and/or cellulose, having an essential role to the nutrient cycle of the environment. Some of them establish close relationship with the substrate and can be considered host-specific to the plant that they decay (Kendrick 2000; Deacon 2006; Webster \& Weber 2007).

About the terms used for the ecological relationships between saprobe fungi and living or dead hosts, Zhou \&
Hyde (2001) proposed a redefinition of these terms. The term "specificity" would imply in the relationship between a living host and a fungus, thus, would not be applied to the saprophytic species; the term "exclusivity" would be the exclusive occurrence of a saprobe in a particular host groups, while "recurrence" would be the frequent or predominant occurrence of a parasitic or saprobe fungus in a particular host or host groups in the same habitat. This last term was previously referred to "preference" (Lindblad 2000; Gilbert and Sousa 2002; Gilbert et al. 2008). However, Zhou \& Hyde (2001) suggested that "preference" should not be used for fungi, because it would imply in "act of volition on the part of the fungus".

The fungal community from a particular environment is related, among other factors, to the substrate availability

\footnotetext{
${ }^{1}$ Departamento de Micologia, Universidade Federal de Pernambuco, Av. Prof. Nelson Chaves s/n, 50760-420, Recife, PE, Brazil

${ }^{2}$ Departamento de Zoologia, Universidade Federal de Pernambuco, Av. Prof. Nelson Chaves s/n, 50760-420, Recife, PE, Brazil

* Corresponding author: geomycota@gmail.com
} 
(plant species composition, for example). So, in low diversity environments, like mangroves, the relationships between fungi and plants would be more easily observed (Gilbert and Sousa 2002).

In Brazil, some studies about lignolytic Agaricomycetes in mangroves were published (Sotão et al. 1991; Almeida Filho et al. 1993; Gugliotta \& Capelari 1995; Campos and Cavalcanti 2000; Campos et al. 2003; Baltazar et al. 2009; Nogueira-Melo et al. 2014). However, none of them provided information about the interactions between fungi and mangrove plants.

Thus, this study aimed to investigate and report for the first time the ecological interactions between lignolytic Agaricomycetes and host plants in Brazilian mangroves and to verify if these interactions are significantly different from other mangroves.

\section{Materials and methods}

\section{Study site}

Brazilian mangroves extend from the state of Amapá $\left(4^{\circ} 30^{\prime} \mathrm{N}\right)$ to Santa Catarina (28 $\left.30^{\circ} \mathrm{S}\right)$, varying significantly in plant growth form, species distribution patterns, and stand structure, in spite of the limited floristic diversity (Schaeffer-Novelli, 1995). Five species of mangrove trees are recorded in the Northeast region: Rhizophora mangle L., Avicennia schaueriana Stapf. and Leech, A. germinans L., Laguncularia racemosa (L.) Gaertn and Conocarpus erectus L. (Cintrón \& Schaeffer-Novelli 1992).

The study was conducted in four mangroves in the state of Pernambuco, Northeast Brazil: Ariquindá river (AR) (35 06'6"W and 08 41'28"S), Mangrove at Maracaípe river (MA) (3500'29"W and 08'32'22.8”S), Mangrove at Santa Cruz Chanel (SC) (0746'52.61"S and 34 ${ }^{\circ} 52^{\prime}$ '53.3”W) and Mangrove at Timbó river (TI) (07 $51^{\prime} 24.8^{\prime \prime S}$ and $\left.34^{\circ} 50^{\prime} 32.7^{\prime \prime} \mathrm{W}\right)$. The studied areas are fringe-type mangrove forests, as they develop along the margins of protected coasts (Cintrón \& Schaefer-Novelli 1980), and are basically composed of $R$. mangle, A. schaueriana and L. racemosa (Schuler et al. 2000). In this study, the mangroves SC and TI had predominance of $A$. schaueriana, while AR and MA of $R$. mangle.

The climate in these areas is defined by Köepen-Geiger classification as a borderline between tropical monsoon (Am) and tropical wet and dry savanna (As instead of Aw, when the dry season occurs during the time of higher sun and longer days) (Peel et al. 2007; Chen \& Chen 2013).

\section{Basidiomata collections and field sampling procedure}

For basidiomata collection, one stand of $10000 \mathrm{~m}^{2}(40 \times$ $250 \mathrm{~m}$ ) was established in each mangrove using the Global Positioning System - GPS. Eight surveys in each stand were undertaken (April to September 2009, December 2009 and March 2010, totaling 32 surveys) and all basidiomata were collected.

For the estimate of the proportion of available living and dead substrate, an imaginary line of $250 \mathrm{~m}$ was delimited inside each stand. On the starting $(0 \mathrm{~m})$, intermediate (125 $\mathrm{m}$ ) and final points $(250 \mathrm{~m})$, three other lines of $40 \mathrm{~m}$ long (20 $\mathrm{m}$ on each side) were delimitated perpendicularly to the main line. The living or dead substrate present in these lines, with or without basidiomata, were quantified. The values for each line were summed and the proportion of each species and condition of the substrate were calculated for each stand. Based on the plant species in the studied areas, six categories of substrate were proposed: living $A$. schaueriana (LA), dead A. schaueriana (DA), living R. mangle (LR), dead R. mangle (DR), living L. racemosa (LV) and dead L. racemosa (LM). Fungi found on dead parts of living plants were considered as degrading dead tissue.

\section{Taxonomy}

After collections, the specimens were analyzed macro(shape, color, hymenial surface) and micromorphologically (hyphal system, presence/absence and measurements of sterile structures and basidiospores). Microscopical observations were made from slide preparations with $5 \%$ $\mathrm{KOH}$, stained with $1 \%$ of aqueous phloxine, and Melzer's reagent (Ryvarden 1991). Color designation followed Watling (1969). The material was identified using specialized literature (Ryvarden \& Johansen 1980; Gilbertson \& Ryvarden 1986; Hjortstam et al. 1987; 1988; Hjortstam \& Ryvarden 1990; Boidin et al. 1997; Boidin \& Gilles 2000; Ryvarden 2004) and incorporated to the Herbarium URM. The nomenclature for Agaricomycetes followed the Index Fungorum (www.indexfungorum.org).

\section{Statistical Analyses}

Species abundance values were represented by the number of occurrence of specimens/individuals on each substrate; one specimen/individual may be represented by several basidiomata (Nogueira-Melo et al. 2014). For the analysis, we considered the species with more than five specimens to reduce error type II probability. The binomial probability test was applied to the species occurrences using BioEstat 5.0 program (Ayres et al. 2007). The level of significance was set at $\mathrm{p}<0.05$ for all analyses.

\section{Results and discussion}

Three hundred seventy two plants were counted, 135 belonging to LR, 111 to DR, 86 to LA, 35 to DA, four to LL and one to DL. It was observed that the mangrove areas differ in the proportion of plant substrate, with predominance of LR in Rio Formoso (74), DR in Maracaípe (63) and LA in Maria Farinha and Itamaracá (48 and 38 respectively). 
Table 1. Lignolytic Agaricomycetes abundance by substrate category in Pernambuco mangroves. DR = dead Rhizophora mangle; DA = dead Avicennia schaueriana; LA = living A. schaueriana; LR = living R. mangle; LL = living Laguncularia racemosa; $\mathrm{DL}=$ dead L. racemosa;

\begin{tabular}{|c|c|c|c|c|c|c|}
\hline Species & DR & DA & LA & LR & LL & DL \\
\hline Asterostroma cervicolor (Berk. and M.A. Curtis) Massee & 2 & & & & & \\
\hline Cerinomyces aculeatus N. Maekawa & 1 & & & & & \\
\hline Ceriporia spissa (Schwein. ex Fr.) Rajchenb. & 2 & & & 2 & & \\
\hline Cerocorticium molle (Berk. and M.A. Curtis) Jülich & 4 & 2 & & 3 & & \\
\hline Coriolopsis hostmannii (Berk.) Ryvarden & & 10 & 1 & & & \\
\hline Fomitopsis nivosa (Berk.) Gilb. and Ryvarden & 5 & 1 & & & & \\
\hline Gleodontia discolor (Berk. and M.A. Curtis) Boidin & 1 & & 1 & & 1 & \\
\hline Gloeocystidiellum triste Hjortstam and Ryvarden & 2 & & 1 & & & \\
\hline Gloeocystidiopsis cf. salmonea (Burt) Boidin, Lanq. and Gilles & 1 & 1 & & & & \\
\hline Gloeophyllum striatum (Sw.) Murrill & 65 & & & & & \\
\hline Gloeoporus dichrous (Fr.) Bres. & 1 & & & & & \\
\hline Hexagonia hydnoides (Sw.) M. Fidalgo & 8 & 6 & & & & \\
\hline Hjortstamia amethystea (Hjortstam and Ryvarden) Boidin and Gillus & 2 & 5 & & 1 & & \\
\hline Hyphoderma iguazuense Hjortstam and Ryvarden & 6 & 3 & & & 1 & \\
\hline Hyphoderma sp & 1 & & & & & \\
\hline Lentinus bertieri (Fr.) Fr. & & & & & 1 & \\
\hline Lopharia sp & 1 & & & & & \\
\hline Loweporus tephroporus (Mont.) Ryvarden & & & 1 & & & \\
\hline Perenniporia guyanensis Decock and Ryvarden & 8 & & 1 & & & \\
\hline Phanerochaete australis Jülich & 1 & & & & & \\
\hline Phellinus contiguus (Pers.) Pat. & & 1 & & & & \\
\hline Phellinus gilvus (Schwein.) Pat. & 8 & 6 & 2 & 1 & & \\
\hline Phellinus mangrovicus (Imazeki) Imazeki & 2 & & & & & \\
\hline Phellinus rhytiphloeus (Mont.) Ryvarden & & & 1 & & & \\
\hline Phellinus rimosus (Berk.) Pilát & 1 & & & & & \\
\hline Phlebiopsis ravenelii (Cooke) Hjortstam & 3 & 1 & & & & \\
\hline Punctularia strigosozonata (Schwein.) P.H.B. Talbot & & 1 & & & & \\
\hline Pycnoporus sanguineus (L.) Murrill & & & 1 & & & \\
\hline Resupinatus poriaeformis (Pers.) Thorn, Moncalvo and Redhead & & 1 & & & & \\
\hline Schizophyllum commune Fr. & 2 & 6 & & 1 & & \\
\hline Schizopora paradoxa (Schrad.) Donk & 18 & 3 & 1 & 4 & & \\
\hline Trichaptum biforme (Fr.) Ryvarden & 7 & 24 & 8 & & 7 & 1 \\
\hline Truncospora detrita (Berk.) Decock & 8 & & 1 & 1 & & \\
\hline
\end{tabular}

Two hundred seventy four specimens belonging to 33 species of Agaricomycetes were collected (Tab. 1, Fig. 1). The occurrence values of Agaricomycetes in L. racemosa were not considered in the analysis, since the low number of individuals of this plant species may cause distortion or overestimation of $p$ values.

Thirteen species occurred more than five times and were sufficiently abundant for the analysis (Tab. 2). Except for C. molle, whose occurrence values did not differ between the substrate categories, 12 species presented significant $p$-values. Coriolopsis hostmanii, $H$. amethystea, S. commune e T. biforme occurred mainly in DA, while G. striatum, in DR. Besides, F. nivosa, H. hydnoides, H. iguazuense, P. gilvus, $P$. guyanensis, $S$. paradoxa and T. detrita occurred more than expected in dead substrates, regardless of the plant species (Tab. 2).

Except for C. molle, all the abundant species for ecological analysis occurred significantly more in dead substrates (Tab. 2). This is expected for lignolytic Agaricomycetes which are, in general, saprophytic and degrade dead plant tissue being the main agents decomposing trees of the forest (Kendrick 2000; Webster and Weber 2007).

Additionally, the wood characteristics may also influence the occurrence of wood decay fungi found in this study. For example, even with the higher frequency of LR on the studied transects, which could have influenced the hostspecificity, the test showed that no species occurred in living substrates. This observation was more evident in R. mangle than A. schauerianna. Rhizophora species are known as great producers of tannin, a compound not produced by Avicennia species (Erickson et al. 2004). Rhizophora mangle has 20 to $30 \%$ of the compound in the bark, which characterizes the reddish color of the trunk (Haslam 1966). The tannin is a phenolic compound produced by the plant, considered a potent inhibitor of enzymes, of processes of decay and of attack by herbivores and phytopathogenic microorganisms. When the plant dies, the tannin levels fall, enabling the growth of decomposer fungi and other organisms (Silva \& Silva 1999). 


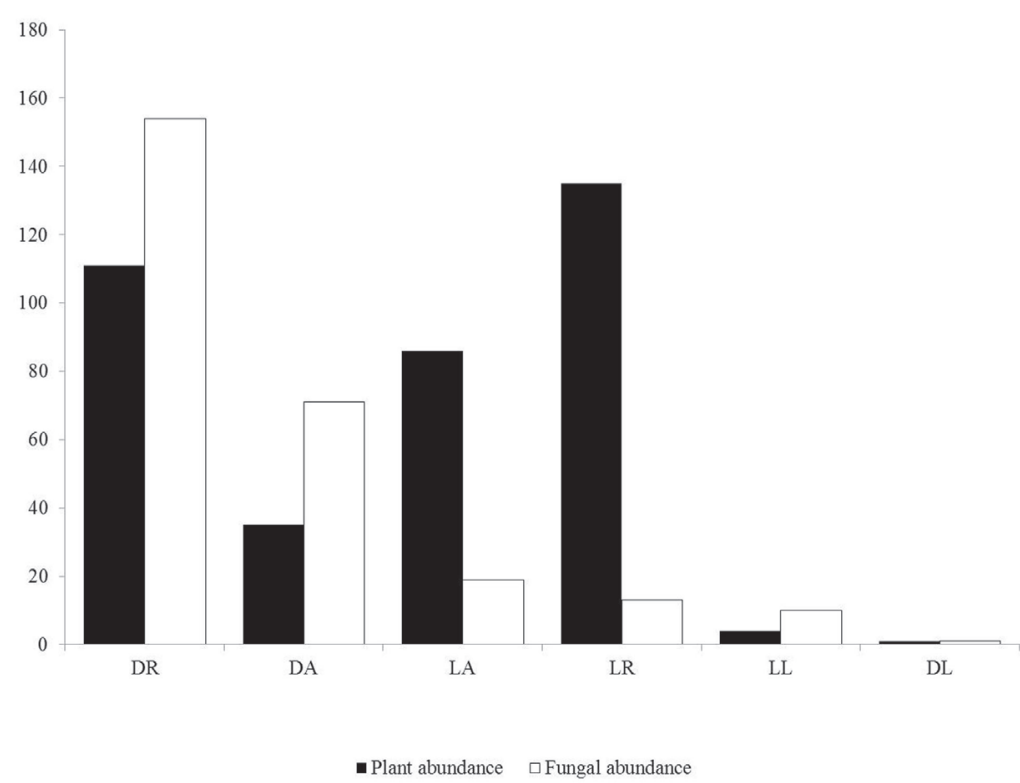

Figure 1. Number of individuals of mangrove plants and fungi by substrate category. DR = dead Rhizophora mangle; DR = dead Rhizophora mangle; DA = dead Avicennia schaueriana; LA = living A. schaueriana; LR = living R. mangle; LL = living Laguncularia racemosa; $\mathrm{DL}=\operatorname{dead} L$. racemosa.

Table 2. Lignolytic Agaricomycetes considered for the analysis of predominance by substrate category. DR = dead Rhizophora mangle; $\mathrm{DA}=\operatorname{dead}$ Avicennia schaueriana; LA = living A. schaueriana; LR = living R. mangle; $\mathrm{pHS}=$ level of significance for host species; $\mathrm{pCS}=$ level of significance for condition of the substrate (dead or living).

\begin{tabular}{|c|c|c|c|c|c|c|}
\hline Species & DR & DA & LA & LR & pHS & pCS \\
\hline Cerocorticium molle (Berk. and M.A. Curtis) Jülich & 4 & 2 & & 3 & 0.3862 & 0.0970 \\
\hline Coriolopsis hostmannii (Berk.) Ryvarden & & 10 & 1 & & $<0.0001$ & $<0.0001$ \\
\hline Fomitopsis nivosa (Berk.) Gilb. and Ryvarden & 5 & 1 & & & 0.3584 & 0.0040 \\
\hline Gloeophyllum striatum (Sw.) Murrill & 65 & & & & $<0.0001$ & $<0.0001$ \\
\hline Hexagonia hydnoides (Sw.) M. Fidalgo & 8 & 6 & & & 0.2158 & $<0.0001$ \\
\hline Hjortstamia amethystea (Hjortstam and Ryvarden) Boidin and Gillus & 2 & 5 & & 1 & 0.0432 & 0.0016 \\
\hline Hyphoderma iguazuense Hjortstam and Ryvarden & 6 & 3 & & & 0.4911 & 0.0002 \\
\hline Truncospora detrita (Berk.) Decock & 8 & & 1 & 1 & 0.1482 & 0.0036 \\
\hline Perenniporia guyanensis Decock and Ryvarden & 8 & & 1 & & 0.1482 & 0.0036 \\
\hline Phellinus gilvus (Schwein.) Pat. & 8 & 6 & 2 & 1 & 0.04 & 0.0004 \\
\hline Schizophyllum commune Fr. & 2 & 6 & & 1 & 0.0402 & 0.0093 \\
\hline Schizopora paradoxa (Schrad.) Donk & 18 & 3 & 1 & 4 & 0.4060 & $<0.0001$ \\
\hline Trichaptum biforme (Fr.) Ryvarden & 1 & 24 & 8 & & $<0.0001$ & 0.0022 \\
\hline Number of trees & 111 & 35 & 86 & 135 & & \\
\hline
\end{tabular}

Based on the concepts proposed by Zhou \& Hyde (2001), in our study, host-exclusivity and host-recurrence were found. No host-specificity was observed. Six of the 13 analyzed species showed predominance in one of the host categories. Gloeophyllum striatum was host-exclusive in $R$. mangle, while $C$. hostmanii, $H$. amethystea, P. gilvus, $S$. commune and T. biforme were host-recurrence in $A$. schauerianna.

Similar results were also obtained by Gilbert \& Sousa (2002) and Gilbert et al. (2008). In mangroves of Panama, Gilbert \& Sousa (2002) found nine sufficiently abundant Agaricomycetes for statistical analysis, of which five showed host-preference (host-recurrence sensu Zhou \& Hyde 2001) in three plant species, while in mangroves of Micronesia, Gilbert et al. (2008) reported host-recurrence between five species of Agaricomycetes and three plant species.

In Brazil, host-specificity has already been reported by Drechsler-Santos et al. (2010) in the Caatinga [a Brazilian ecoregion characterized mostly by the xerophytic vegetation and hot and dry (BSh) climate], where Phellinotus piptadeniae was differentially frequent on Piptadenia moniliformes and Phellinotus neoaridus on Caesalpinia microphylla.

Of the collected species, only P. mangrovicus seems to be restricted to mangroves (Larsen \& Cobb-Poulle 1990; Campos and Cavalcanti 2000; Ryvarden 2004), but it was not sufficiently abundant for statistical analysis. The 
other species are considered host-generalists, (including $G$. striatum, which in the current study was host-exclusive in R. mangle), being mentioned previously in other hosts when collected in high-diverse ecosystems (Ryvarden \& Johansen 1980; Hjortstam et al. 1987; Gilbertson \& Ryvarden 1986; Hjortstam \& Ryvarden 1990; Boidin et al. 1997; Boidin \& Giles 2000; Lindblad 2000).

The data here presented may support the hypothesis of Gilbert \& Sousa (2002) that in environments of low diversity, such as mangroves, the differential occurrence of a fungus in a host may happen more easily, since in those environments plant diversity is low and, therefore, the number of suitable host plants is higher.

Overall, the results were those expected for environments with low richness of plants, since about half of the species sufficiently abundant for the statistical analyses occupied differentially one of the established categories of substrate. However, to evaluate these relationships, the mangrove cannot be considered as a homogeneous ecosystem because there are many factors that influence locally the distribution and composition of plant species, which, in turn, will influence the distribution of fungi.

\section{Acknowledgements}

The authors would like to thank the laboratory colleagues during the field trips; Leif Ryvarden and Karl-Henrik Larsson for identifying some species; and Miles Hudson for English improvements. This research was supported by the Conselho Nacional de Desenvolvimento Científico e Tecnológico (CNPq, master scholarship of GSNM) and by FACEPE (APQ 0444-2.03/08).

\section{References}

Almeida-Filho OM, Bueno R, Bononi VLR. 1993. Algumas espécies de fungos basidiomicetos dos manguezais do Estado de São Paulo. Hoehnea 20: 87-92.

Ayres M, Ayres JRM, Ayres DL, Santos AAS. 2007. BioEstat: Aplicações estatísticas nas áreas de ciências biomédicas. 5th. edn. Belém, Guanabara.

Baltazar JM, Trierveiler-Pereira L, Loguercio-Leite CA. 2009. Checklist of xylophilous basidiomycetes (Basidiomycota) in mangroves. Mycotaxon 107: 221-224.

Boidin J, Gilles G. 2000. Basidiomycetes Aphyllophorales de L'ile de la reunion XXI - Suíte. Mycotaxon 75: 357-387.

Boidin J, Lanquetin P, Gilles G. 1997. Le genre Gleocystidiellum sensu latu (Basidiomycotina). Bulletin de la Societé Mycologique de France 113.

Campos EL, Cavalcanti MAQ. 2000. Primeira ocorrência de Phellinus mangrovicus (Imaz.) Imaz. para o Brasil. Acta Botanica Brasilica 14: 263-265.

Campos EL, Sotão HMP, Cavalcanti MAQ, Luz AB. 2003. Basidiomycetes de manguezais da APA de Algodoal-Maiandeua, Pará, Brasil. Boletim do Museu Paraense Emílio Goeldi Série Ciências Naturais 1: 97-102. Chen AD, Chen HW. 2013. Using the Köppen classification to quantify climate variation and change: An example for 1901-2010. Environmental Development. 6: 69-79.

Cintrón G, Schaeffer-Novelli Y. 1980. Introducción a la ecologia del manglar. São Paulo, Instituto Oceanográfico USP.

Cintrón G; Schaeffer-Novelli Y. 1992. Ecology and management of new world mangroves. In: Seeliger U. (ed.) Coastal plant communities of Latin America. New York, Academic Press. p. 233-258.

Deacon JW. 2006. Fungal biology. 4th. edn. Malden, Blackwell Publishing.

Drechsler-Santos ER, Santos PJP, Gibertoni TB, Cavalcanti MAQ. 2010. Ecological aspects of Hymenochaetaceae in an area of Caatinga (semiarid) in Northeast Brazil. Fungal Diversity 42: 71-78.

Erickson AA, Bell SS, Dawes CJ. 2004. Does mangrove leaf chemistry help explain crab herbivory patterns?. Biotropica 36: 333-343.

Gilbert GS, Gorospe J, Ryvarden L. 2008. Host and habitat preferences of polypore fungi in Micronesian tropical flooded forests. Mycological Research 112: 674-680.

Gilbert GS, Sousa WP. 2002. Host specialization among wood-decay polypore fungi in a Caribbean mangrove forest. Biotropica 34: 396-404.

Gilbertson RL, Ryvarden L. 1986. North American Polypores Vol. 1. Oslo, Fungiflora.

Gugliotta AM, Capelari M. 1995. Polyporaceae from Ilha do Cardoso, SP, Brazil. Mycotaxon 56: 107-113.

Haslam E. 1966. Chemistry of vegetable tanins. London, Academy Perss.

Hjortstam K, Larsson KH, Ryvarden L. 1987. The Corticiaceae of North Europe Vol. 1. Oslo, Fungiflora.

Hjortstam K, Larsson KH, L Ryvarden. 1988. The Corticiaceae of North Europe Vol. 2. Oslo, Fungiflora.

Hjortstam K, Ryvarden L. 1990. Lopharia and Porostereum (Corticiaceae) Synopsis Fungorum 4. Oslo, Fungiflora.

Kendrick B. 2000. The fifth kingdom. 2nd. edn. Newburyport, MA: Focus Information Group.

Larsen M, Cobb-Poule LA. 1990. Phellinus (Hymenochaetaceae). A survey of the world taxa Synopsis Fungorum 3. Oslo, Fungiflora.

Lindblad I. 2000. Host specificity of some wood-inhabiting fungi in a tropical forest. Mycologia 92: 399-405.

Nogueira-Melo GS, Santos PJP, Gibertoni TB. 2014. The community structure of macroscopic basidiomycetes (Fungi) in Brazilian mangroves influenced by temporal and spatial variations. Revista de Biología Tropical 62: 1587-1595.

Peel MC, Finlayson BL, McMahon TA. 2007. Updated world map of the Köppen-Geiger climate classification. Hydrology and Earth System Sciences 11: 1633-1644.

Ryvarden L. 1991. Genera of polypores, nomenclature and taxonomy. Synopsis Fungorum 5. Oslo, Fungiflora.

Ryvarden L. 2004. Neotropical Polypores. Part 1. Synopsis Fungorum 19. Oslo, Fungiflora.

Ryvarden L, Johansen I. 1980. A preliminary polypore flora of East Africa. Oslo, Fungiflora.

Schaeffer-Novelli, Y. 1995. Manguezal ecossistema entre a terra e o mar. São Paulo, Caribbean Ecological Research.

Schuler CAB, Andrade VC, Santos DS. 2000. O manguezal: composição e estrutura. In: Barros HM, Esquinazi L, Macedo SJ, Lima T. (eds.) Gerenciamento participativo de estuários e manguezais. Recife, Editora Universitária da Universidade Federal de Pernambuco. p. 89-102.

Silva MR, Silva MAAP. 1999. Aspectos nutricionais de fitatos e taninos. Revista de Nutrição 12: 5-19.

Sotão HMP, Bononi VLR, Figueiredo TS. 1991. Basidiomycetes de manguezais da Ilha de Maracá, Amapá, Brasil. Serie Botanica 7: 109-114.

Watling R. 1969. Colour Identification Chart. Edinburgo, Her Majesty's Stationary Office.

Webster J, Weber RWS. 2007. Introduction to Fungi. 3rd. edn. Cambridge, Cambridge University Press.

Zhou D, Hyde KD. 2001. Host-specificity, host-exclusivity, and hostrecurrence insaprobic fungi. Mycological Ressearch 5: 1449-1457. 